\title{
A Meta-Analysis of Acute Kidney Injury in Patients Undergoing Hip Fracture Surgery: Prevalence and Risk Factors
}

\author{
Yan-Li Zhang \\ Wuwei people's hospital \\ Yan-Chuang Pu ( $\sim$ lcsw666@163.com ) \\ Wuwei people's hospital \\ Jin Wang \\ Wuwei people's hospital \\ Zi-Cai Li \\ wuwei people's hospital \\ Hu-Lin Wang \\ Wuwei people's hospital
}

\section{Research article}

Keywords: Kidney Injury; Prevalence, Risk Factor; Hip Fracture; Meta-analysis

Posted Date: May 26th, 2020

DOI: https://doi.org/10.21203/rs.3.rs-29764/v1

License: (a) (1) This work is licensed under a Creative Commons Attribution 4.0 International License. Read Full License 


\section{Abstract}

Objective: Acute kidney injury(AKI) was a frequent complication following hip fracture surgery, but recent studies reported inconsistent findings. The purpose of our study was to systematically clarify the prevalence and risk factors of AKI after hip fracture surgery.

Methods: Pubmed, Embase, and Web of Science were searched from the inception to March 2020 to identify observational studies investigating the prevalence and risk factors of AKI in patients undergoing hip fracture surgery. Pooled prevalence and odds ratios(ORs) with $95 \%$ confidence intervals(Cls) were estimated using random-effect model. Publication bias was evaluated with a funnel plot and statistical test. All the statistical analyses were performed using STATA version 12.0.

Results: A total of 11 studies with 16,421 patients were included in the current meta-analysis. The pooled prevalence of AKI in patients undergoing hip fracture surgery was $17 \%(95 \% \mathrm{Cl}, 14 \%-21 \%)$. Postoperative serum albumin(OR $1.80 ; 95 \% \mathrm{Cl}, 1.38-2.36)$ was a significant predictor for AKI. Age(OR 1.01; 95\% Cl, 0.95-1.07) and ACE inhibitors(OR 1.38; 95\%Cl, 0.92-2.07) were also associated with increased risk of AKI, but the results were not statistically significant. No significant publication bias was identified through statistical tests(Egger's test, $p=0.258$ and Begg's test, $p=0.087$ ).

Conclusions: The pooled AKI following hip fracture surgery was approximately $17 \%$. Postoperative serum albumin was a potential significant risk factor for AKI.

\section{Introduction}

The worldwide population is continuously aging, thereby leading to an increase in the prevalence of osteoporotic hip fractures. ${ }^{1,2} \mathrm{~A}$ recent statistical estimation predicts that the patients receiving surgical interventions for hip fracture will double by 2050 owing to the aging of population. ${ }^{3}$ Furthermore, hip fracture is a major public health challenge, for it causes serious morbidity, death, and socioeconomic burden. ${ }^{3}$

Acute kidney injury (AKI) is a clinical syndrome featured with a sudden impairment in glomerular filtration and correlates with complex etiologies and pathophysiological processes. Every year, about 13.3 million cases are diagnosed with this intractable syndrome all over the world. ${ }^{4,5}$ Worse still, it has been estimated that AKI results in a considerably mortality ( 1.7 million deaths per year) globally. .5 Notably, AKI is a common postoperative complication in patients undergoing surgical interventions for hip fracture, which closely correlated with prolonged hospital stay, various morbidity and increased mortality ${ }^{6,7}$ Therefore, to adequately understand the landscape of prevalence and risk factors of AKI may largely help to improve outcomes of patients undergoing hip fracture surgery. Nevertheless, the reported prevalence of AKI associated with hip fracture surgery ranged widely from $5-60 \%$ currently. This remarkable range change may be caused by different AKI definition, inconsistent follow-up durations and small sample size, and so on. It is common sense that an inaccurate estimation of AKI prevalence will prevent clinicians to grasp an overview of the disease burden and its natural history, and this makes it hard for them to evaluate whether specific treatment strategies are effective for preventing AKI. Additionally, positively monitoring and coping with the risk factors for AKI may also do good to AKI prevention. ${ }^{8,9}$

Therefore, in this study we performed a meta-analysis and systematic review to summarize the prevalence and associated risk factors for AKI in patients undergoing surgical treatment for hip fracture.

\section{Methods}

This meta-analysis was undertaken according to the guideline of the Meta-analysis of Observational Studies in Epidemiology(MOOSE) checklist and the Preferred Reporting Items for Systematic Reviews and Meta-Analysis(PRISMA) statement. ${ }^{10,11}$

\section{Search Strategy And Study Selection}

A systematic literature search of Pubmed, Embase, and Web of Science was conducted from inception to March 2020 to retrieve studies that reported the prevalence and risk factors of AKI in patients undergoing surgical interventions for hip fracture. The systematic search strategy was established using the terms of "acute kidney injury", "hip fracture surgery" and their variants. A manual search for potentially eligible studies was performed as well by screening the references of the included literature. 


\section{Selection Criteria}

Eligible studies should be cohort studies, case-control studies, or cross-sectional studies, which must provide the data to estimate prevalence and risk factors of AKI in patients undergoing surgery for hip fracture. Only studies published in English were considered. The Retrieved studies were individually evaluated for eligibility by the two investigators independently. Discrepancies in eligible study selection were resolved via discussion and mutual consensus.

\section{Data Abstraction And Quality Assessment}

We applied the pre-designed table to extract the following information: first author, publication year, study period, country, operation type, case number, the number of patients with AKI, AKI definition and risk factors of AKI. The primary outcome was the prevalence of AKI after surgery for hip fracture. The secondary outcome was the odds ratio (OR) with corresponding $95 \%$ confidence interval $(\mathrm{Cl})$, which evaluated the relevant risk factors of AKI after surgery for hip fracture. Furthermore, only ORs with Cls generated from the multivariate analysis in the included studies were extracted. Two authors independently assessed the risk of bias of each eligible study according to the Newcastle-Ottawa Scale (NOS) score. ${ }^{12}$

\section{Statistical analysis}

The prevalences of AKI after surgery for hip fracture were extracted from eligible studies. Pooled estimated prevalences and $95 \% \mathrm{Cls}$ were calculated with a random effect model. Odds ratios (ORs) with $95 \% \mathrm{Cls}$ for risk factors were combined with a random effect model when substantial statistical heterogeneity existed across the included studies. Only candidate risk factors reported in two or more eligible studies on multivariable model were subjected for meta-analysis. $\left.\right|^{2}$ statistic was applied to evaluate the statistical heterogeneity across eligible studies was assessed using with $P$ value for $Q<0.05$ or statistic $\mathrm{I}^{2}>50 \%$ regarded as substantial heterogeneity. ${ }^{13,14}$ Meta-regression analysis on publication time, sample size and NOS score were used to explore the potential source of heterogeneity. Sensitivity analysis was undertaken by deleting one study each step to investigate the influence of single study on the overall pooled estimated prevalence of AKI after surgery for hip fracture. Subgroup analyses based on region, sample size, study design, AKI Definition, and NOS score for the primary outcome were conducted to explore the prevalence of AKI in sub-populations. Publication bias was evaluated by Begg's and Egger's tests, in which $\mathrm{P}<0.05$ and asymmetric funnel plot indicated significant publication bias. ${ }^{15,16} \mathrm{~A}$ two-sided $\mathrm{P}<0.05$ was identified as statistical significance. All the statistical analyses were performed using STATA 12.0 (Stata Corporation, College Station, TX, USA).

\section{Results}

\section{Study selection and characteristics}

A total of 810 items were identified through systematically searching three databases. Furthermore, the full texts of 57 articles were screened for possible eligibility following removing duplicated and irrelative items. Eventually, a total of 11 studies with 16,421 patients were included in the current meta-analysis. $3,6,17-25$ The flow chart of study selection was summarized in Fig. 1. The publication time of included studies ranged from 2010 to 2020. Seven studies were performed in Asia 6,18,19,21,22,24,25, while the other four in Europe $^{3,17,20,23}$. The operation types, study design, and AKI definition of included studies were also different from each other. The whole NOS score of included studies ranged from 6 to 8 points, which suggested that the quality of included studies were moderate to high level. The detailed baselines characteristics and quality assessment of included studies were showed in Table 1 and Table 2 . 
Table 1

Baseline characteristics of included studies in the meta-analysis

\begin{tabular}{|c|c|c|c|c|c|c|c|c|}
\hline Study/year & $\begin{array}{l}\text { Study } \\
\text { period }\end{array}$ & Country & Operation & Age(years) & $\begin{array}{l}\mathbf{N} \\
\text { with } \\
\text { AKI }\end{array}$ & $\begin{array}{l}\mathbf{N} \\
\text { total }\end{array}$ & $\begin{array}{l}\text { AKI } \\
\text { Definition }\end{array}$ & $\begin{array}{l}\text { Study } \\
\text { design }\end{array}$ \\
\hline Craig $2012^{17}$ & $\begin{array}{l}\text { September } \\
\text { and } \\
\text { November } \\
2010\end{array}$ & $\begin{array}{l}\text { United } \\
\text { Kingdom }\end{array}$ & $\begin{array}{l}\text { Surgery for } \\
\text { fractured neck } \\
\text { of femur }\end{array}$ & $\begin{array}{l}\text { Study group } \\
\text { (80.3 years); } \\
\text { control } \\
\text { group } \\
\text { (83.6 years) }\end{array}$ & 13 & 100 & $\begin{array}{l}\text { An increase } \\
\text { in serum } \\
\text { creatinine by } \\
\text { over } 50 \% \text { of } \\
\text { baseline }\end{array}$ & $\begin{array}{l}\text { Historical } \\
\text { cohort study }\end{array}$ \\
\hline Ulucay 201218 & $\begin{array}{l}2007- \\
2010\end{array}$ & Turkey & $\begin{array}{l}\text { Surgery for } \\
\text { femoral neck } \\
\text { fracture }\end{array}$ & $>65$ years & 25 & 163 & $\begin{array}{l}\text { AKIN } \\
\text { classification }\end{array}$ & $\begin{array}{l}\text { Prospective } \\
\text { cohort study }\end{array}$ \\
\hline Marty $2016^{3}$ & $\begin{array}{l}\text { May- } \\
\text { October } \\
2012\end{array}$ & France & $\begin{array}{l}\text { Hip fracture } \\
\text { surgery }\end{array}$ & $\begin{array}{l}83(75-92) \\
\text { years }\end{array}$ & 29 & 48 & $\begin{array}{l}\text { AKIN } \\
\text { classification }\end{array}$ & $\begin{array}{l}\text { Prospective } \\
\text { cohort study }\end{array}$ \\
\hline $\begin{array}{l}\text { Pedersen } 2016 \\
20\end{array}$ & $\begin{array}{l}2005- \\
2011\end{array}$ & Denmark & $\begin{array}{l}\text { Hip fracture } \\
\text { surgery }\end{array}$ & $>65$ years & 1717 & 13529 & $\begin{array}{l}\text { KDIGO } \\
\text { classification }\end{array}$ & $\begin{array}{l}\text { Regional } \\
\text { cohort study }\end{array}$ \\
\hline Hong 201719 & $\begin{array}{l}2010- \\
2012\end{array}$ & Korea & $\begin{array}{l}\text { Hip fracture } \\
\text { surgery }\end{array}$ & $>65$ years & 95 & 450 & $\begin{array}{l}\text { AKIN } \\
\text { classification }\end{array}$ & $\begin{array}{l}\text { Retrospective } \\
\text { cohort study }\end{array}$ \\
\hline Shin $2018^{6}$ & $\begin{array}{l}2011- \\
2016\end{array}$ & Korea & $\begin{array}{l}\text { Surgery for } \\
\text { intertrochanteric } \\
\text { fracture of the } \\
\text { proximal femur }\end{array}$ & $>60$ years & 57 & 481 & $\begin{array}{l}\text { KDIGO } \\
\text { classification }\end{array}$ & $\begin{array}{l}\text { Retrospective } \\
\text { cohort study }\end{array}$ \\
\hline $\begin{array}{l}\text { Frenkelrutenberg } \\
2019^{21}\end{array}$ & $\begin{array}{l}2012- \\
2016\end{array}$ & Israel & $\begin{array}{l}\text { Surgery for } \\
\text { fragility hip } \\
\text { fractures }\end{array}$ & $>65$ years & 55 & 217 & $\begin{array}{l}\text { AKIN } \\
\text { classification }\end{array}$ & $\begin{array}{l}\text { Retrospective } \\
\text { cohort study }\end{array}$ \\
\hline Jang $2019^{22}$ & $\begin{array}{l}2011- \\
2015\end{array}$ & Korea & $\begin{array}{l}\text { Femoral neck } \\
\text { fracture surgery }\end{array}$ & $\begin{array}{l}77.6(65- \\
97) \text { years }\end{array}$ & 44 & 248 & $\begin{array}{l}\text { KDIGO } \\
\text { classification }\end{array}$ & $\begin{array}{l}\text { Retrospective } \\
\text { cohort study }\end{array}$ \\
\hline $\begin{array}{l}\text { Rantalaiho } 2019 \\
23\end{array}$ & $\begin{array}{l}2017- \\
2018\end{array}$ & Finland & $\begin{array}{l}\text { Hip fracture } \\
\text { surgery }\end{array}$ & $>65$ years & 40 & 475 & $\begin{array}{l}\text { KDIGO } \\
\text { classification }\end{array}$ & $\begin{array}{l}\text { Retrospective } \\
\text { cohort study }\end{array}$ \\
\hline Kang 202024 & $\begin{array}{l}2011- \\
2016\end{array}$ & Korea & $\begin{array}{l}\text { Hip fracture } \\
\text { surgery }\end{array}$ & 70.1 years & 25 & 550 & $\begin{array}{l}\text { AKIN } \\
\text { classification }\end{array}$ & $\begin{array}{l}\text { Case-control } \\
\text { study }\end{array}$ \\
\hline Küpeli 202025 & $\begin{array}{l}\text { January } \\
(1-7) \\
2018\end{array}$ & Turkey & $\begin{array}{l}\text { Hip fracture } \\
\text { surgery }\end{array}$ & $>65$ years & 28 & 160 & $\begin{array}{l}\text { KDIGO } \\
\text { classification }\end{array}$ & $\begin{array}{l}\text { Retrospective } \\
\text { descriptive } \\
\text { study }\end{array}$ \\
\hline
\end{tabular}


Table 2

NOS score of included studies in the meta-analysis

\begin{tabular}{|c|c|c|c|c|}
\hline Study & Selection & Comparability & Exposure & Total Score \\
\hline Craig $2012^{17}$ & 2 & 2 & 3 & 7 \\
\hline Ulucay 201218 & 3 & 2 & 3 & 8 \\
\hline Marty $2016^{3}$ & 3 & 2 & 3 & 8 \\
\hline Pedersen 201620 & 3 & 2 & 3 & 8 \\
\hline Hong $2017^{19}$ & 3 & 2 & 2 & 7 \\
\hline Shin $2018^{6}$ & 3 & 2 & 3 & 8 \\
\hline Frenkelrutenberg 201921 & 2 & 2 & 3 & 7 \\
\hline Jang 201922 & 3 & 2 & 3 & 8 \\
\hline Rantalaiho 201923 & 2 & 2 & 3 & 7 \\
\hline Kang 202024 & 2 & 2 & 3 & 7 \\
\hline Küpeli 202025 & 2 & 2 & 2 & 6 \\
\hline \multicolumn{5}{|c|}{ NOS, Newcastle-Ottawa Scale } \\
\hline
\end{tabular}

\section{Postoperative Aki In Patients Undergoing Hip Fracture Surgery}

All the included studies reported the prevalence of postoperative AKI in patients undergoing hip fracture surgery. The pooled prevalence of AKI following hip fracture surgery was $17 \%(95 \% \mathrm{Cl}, 0.14-0.21)$ with substantial heterogeneity $\left(\mathrm{I}^{2}=95 \%\right)(\mathrm{Fig}$. 2). Meta-regressions were conducted to explore the potential sources of statistical heterogeneity. The results indicated that publication time $(p=0.368)$, sample size $(p=0.593)$, and NOS score $(p=0.558)$ may not be the potential sources of statistical heterogeneity. Also, we performed stratified analyses to explore the prevalence of AKI in subgroup patients. In subgroup analyses stratified by region, the prevalence of AKI in Asia(22\%) was higher than that in Europe(12\%). When stratified by sample size, the prevalence of AKI in sample size $>500(40 \%)$ was higher than that in sample size $\leq 500(15 \%)$. In subgroup analysis by study design, the prevalence of AKI in the subgroup of cohort study $(14 \%)$ was lower than that in other subgroup(43\%). Interestingly, the prevalences of AKI in subgroup stratified by AKI definition and NOS score were basically the overall pooled prevalence of AKI. The detailed results of subgroup analyses were showed in Table 3. We also undertook the sensitivity analysis to explore the influence of individual included studies on the overall pooled estimate. We found that the pooled prevalence of POD basically remained stable, which indicated that pooled result was robust and credible(Fig. 3). We further evaluated the potential publication bias using the funnel plot and statistical tests. The funnel plot seemed to be asymmetric, but the statistical results indicated that the publication bias was not statistically significant (Egger's test, $p=0.258$ and Begg's test, $p=0.087$; Fig. 4). 
Table 3

Subgroup analysis for the prevalence of AKI in Patients Undergoing hip fracture surgery

\begin{tabular}{|c|c|c|c|}
\hline Outcomes & $\begin{array}{l}\text { Number } \\
\text { of trials }\end{array}$ & Pooled prevalence with $95 \% \mathrm{Cl}$ & $\mathrm{I}^{2}(\%)$ \\
\hline Primary analysis & 11 & $0.17(0.14-0.21)$ & 95 \\
\hline \multicolumn{4}{|l|}{ Region } \\
\hline Asia & 7 & $0.22(0.15-0.29)$ & 93.9 \\
\hline Europe & 4 & $0.12(0.07-0.18)$ & 97 \\
\hline \multicolumn{4}{|l|}{ Sample size } \\
\hline$>500$ & 2 & $0.40(0.02-0.79)$ & 96.5 \\
\hline$\leq 500$ & 9 & $0.15(0.11-0.18)$ & 94 \\
\hline \multicolumn{4}{|l|}{ Study design } \\
\hline Cohort study & 9 & $0.14(0.11-0.18)$ & 94.1 \\
\hline Others & 2 & $0.43(0.11-0.76)$ & 94.3 \\
\hline \multicolumn{4}{|l|}{ AKI Definition } \\
\hline Self-definition & 1 & $0.12(0.06-0.18)$ & \\
\hline KDIGO & 5 & $0.17(0.09-0.25)$ & 96.7 \\
\hline AKIN & 5 & $0.20(0.15-0.25)$ & 92.4 \\
\hline \multicolumn{4}{|l|}{ NOS score } \\
\hline$>7$ & 5 & $0.17(0.12-0.21)$ & 92.2 \\
\hline$\leq 7$ & 6 & $0.20(0.12-0.29)$ & 95.9 \\
\hline
\end{tabular}

\section{Risk factors for AKI in patients undergoing hip fracture surgery}

We also explore the potential risk factors associated with AKI in patients undergoing hip fracture surgery. A total of seven studies reported AKI-associated risk factors on multivariate or adjusted model(Table 4). 3,6,18,20,22-24 Of these identified risk factors, pooled estimate indicated that postoperative serum albumin(2 studies; OR 1.80; $95 \% \mathrm{Cl}, 1.38-2.36$; Table 5) was a significant predictor for AKI in patients undergoing hip fracture surgery. Age(3 studies; OR 1.01; 95\% Cl, 0.95-1.07; Table 5) and ACE inhibitors(2 studies; OR 1.38; $95 \% \mathrm{Cl}, 0.92-2.07$; Table 5) were also associated with increased risk of $\mathrm{AKI}$ in patients undergoing hip fracture surgery, but the results were not statistically significant. 
Table 4

Risk factors associated with AKI on multivariate model in patients undergoing hip fracture surgery

\begin{tabular}{|c|c|}
\hline Study & Risk factors on multivariate model \\
\hline $\begin{array}{l}\text { Ulucay } \\
201218\end{array}$ & $\begin{array}{l}\text { Age, years: (OR 1.049, 95\%Cl 0.984-1.118); Gender (female):(OR 2.643, 95\%Cl 0.909-7.686); Potassium: (OR 1.688, } \\
\text { 95\%Cl 0.693-4.110); eGFR:(OR 0.945, 95\%Cl 0.921-0.963) }\end{array}$ \\
\hline $\begin{array}{l}\text { Marty } \\
2016^{3}\end{array}$ & $\begin{array}{l}\left.\text { Preop Rl:(OR 0.03, 95\%Cl 0.01-75228);Postop RI:(OR 1.6*10 } 12,95 \% \mathrm{Cl} 3779-679 * 10^{18}\right) ; \text { GFR Preop:(OR 9.7, } 95 \% \mathrm{Cl} \\
\text { 0.88-107); Age, years: (OR 0.92, 95\%Cl 0.84-1.01) }\end{array}$ \\
\hline $\begin{array}{l}\text { Pedersen } \\
2016^{20}\end{array}$ & $\begin{array}{l}\text { Obese patients for AKI } 1 \text { stage(HR 1.4, 95\% CI 1.1-1.8), AKI } 2 \text { stage(HR 1.9, 95\% } \mathrm{Cl} 1.3-3.0) \text {, AKI } 3 \text { stage }(\mathrm{HR} 2.8,95 \% \mathrm{Cl} \\
1.5-4.9)\end{array}$ \\
\hline Shin 2018 & $\begin{array}{l}\text { Age (years):(OR 1.022, 95\% Cl 0.983-1.064); Chronic kidney disease:(OR 3.879, 95\%Cl 1.885-7.981);ACE } \\
\text { inhibitors(OR 1.751, 95\% Cl 0.928-3.302);NSAIDs(OR 0.718, 95\%Cl 0.339-1.291); Koval score(OR 1.067, } 95 \% \mathrm{Cl} \\
0.916-1.244) ; \text { Postoperative serum albumin(OR 1.972, 95\% Cl 1.029-3.779); Postoperative drained blood volume(OR } \\
1.003,95 \% \mathrm{Cl} 0.999-1.007)\end{array}$ \\
\hline $\begin{array}{l}\text { Jang } 2019 \\
22\end{array}$ & 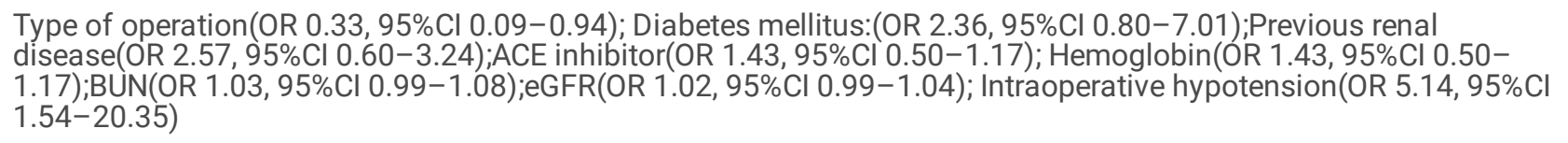 \\
\hline $\begin{array}{l}\text { Rantalaiho } \\
2019^{23}\end{array}$ & Dementia(RR 2.37, 95\%Cl 1.00-4.98); Preoperative sCr:(RR 1.01, 95\%Cl 1.01-1.02) \\
\hline $\begin{array}{l}\text { Kang } 2020 \\
24\end{array}$ & $\begin{array}{l}\text { Hospitalization(OR 1.24, 95\%Cl 0.96-1.57);EBL(OR 1.54, 95\%Cl 1.32-2.44);Postoperative serum albumin(OR 1.77, } \\
95 \% \mathrm{Cl} 1.52-2.74)\end{array}$ \\
\hline \multicolumn{2}{|c|}{$\begin{array}{l}\text { AKI, Acute Kidney Injury; OR, odds ratio; CI, Confidence interval; eGFR, estimated glomerular filtration rate; GFR: glomerular filtration } \\
\text { rate;preop RI: preoperative doppler renal resistive index; postop RI:postoperative doppler renal resistive index; HR, hazard ratio; ACE } \\
\text { inhibitors = angiotensin-converting enzyme inhibitors; NSAIDS = Non-steroidal antiinflammatory drugs; BUN, blood urea nitrogen; } \\
\text { EBL: estimated blood loss }\end{array}$} \\
\hline
\end{tabular}

Table 5

Meta-analysis of risk factors for AKI in Patients undergoing hip fracture surgery

\begin{tabular}{|lll|}
\hline Outcomes & Number of & OR (95\% Cl) \\
& trials & \\
\hline Age & 3 & $1.01(0.95-1.07)$ \\
\hline ACE inhibitors & 2 & $1.38(0.92-2.07)$ \\
\hline Postoperative serum albumin & 2 & $1.80(1.38-2.36)$ \\
\hline eGFR & 2 & $0.98(0.91-1.06)$ \\
\hline $\begin{array}{l}\text { AKI, Acute Kidney Injury; OR, odds ratio; Cl, Confidence interval; ACE inhibitors, angiotensin-converting enzyme inhibitors; eGFR, } \\
\text { estimated glomerular filtration rate }\end{array}$ & 0 \\
\hline
\end{tabular}

\section{Discussion}

The current meta-analysis revealed that AKI was a relatively frequent complication in patients undergoing hip fracture surgery with pooled prevalence ranging from 14 to $21 \%$. Additionally, postoperative serum albumin was identified to be a significant risk factor for AKI following hip fracture surgery.

The current meta-analysis based on 11 observational studies indicated that the overall pooled prevalence of AKI following hip fracture surgery was $17 \%$ with substantial heterogeneity. Considering that the significant heterogeneity may impair the credibility of the pooled estimate, meta-regression was performed to explore the potential sources of statistical heterogeneity. Furthermore, we identified that publication time, sample size, and NOS score may not be associated with significant heterogeneity. Furthermore, we conducted subgroup analysis and sensitivity analysis to explore the prevalence of AKI in sub-population. Interestingly, the results of subgroup analysis and sensitivity analysis were basically consistent with the overall pooled effect, which suggested that the pooled estimate was robust and reliable. A previous meta-analysis showed that the overall estimated prevalence rates of AKI in patients undergoing total hip arthroplasties are $6.3 \% .{ }^{26}$ Obviously, the prevalence of AKI following total hip arthroplasties was lower than that in patients 
undergoing hip fracture surgery. Regardless of the fact that the exact causes for these differences were largely unclear, but surgical workers should attach more importance to the potential AKI in patients undergoing hip fracture surgery. In the study, we also investigated the risk factors for AKI following hip fracture surgery. Pooled analysis showed that postoperative serum albumin was a significant indicator for AKI in patients undergoing hip fracture surgery. Consistent with our results, some previous studies also found that serum albumin level was a potential risk factor for AKI. Thongprayoon et al. revealed that there existed a U-shape correlation between serum albumin levels and AKI in hospitalized patients. ${ }^{27}$ Dos Santos and coworker found that low serum albumin concentration was associated with increased risk of AKI in critically ill patients. ${ }^{28}$ Mechanically, a recent study found that 5Lypoxygenase products induced by albumin overload may be responsible for renal tubulointerstitial injury. ${ }^{29}$ Other risk factors including age, ACE inhibitors, and eGFR were possible predictors for AKI, although the pooled results were not statistically significant. Collectively, perioperative management methods aimed at these risk factors may decrease the risk of AKI after hip fracture surgery.

There also existed several limitations in the current study. Firstly, our meta-analysis showed substantial statistical heterogeneity, which may potentially impair the reliability of the pooled estimate. Subsequently, we performed meta-regression to explore the sources of statistical heterogeneity and none of significant factors were identified to be responsible for heterogeneity. A possible interpretation is that multiple clinical and methodological difference across included studies, but not individual factor contribute to the significant statistical heterogeneity. Irrespective of the statistical heterogeneity, the results of subgroup analysis and sensitivity analysis were basically consistent with the overall pooled effect, which showed the robustness and reliability of the pooled estimate. Secondly, we evaluated the potential publication bias using the funnel plot and statistical tests. The statistical results showed that the publication bias was not statistically significant, but the funnel plot seemed to be asymmetric. Considering the inconsistence, the potential publication bias still cannot be excluded, although we performed a systematic literature search in the meta-analysis. Thirdly, some risk factors reported in included studies were not pooled for meta-analyses owing to limited studies, which may bias the authentic effects for AKI. The pooled analysis based on two studies found that ACE inhibitors may not be a significant risk factor for AKI following hip fracture surgery. Actually, many studies found that ACE inhibitors was a significant predictor for AKI. ${ }^{30-32}$ Also, many risk factors including chronic kidney disease, intraoperative hypotension, and dementia were reported to be significant predictors for AKI, but we did not included for further pooled analyses owing to that they were reported in the limited studies. Therefore, the limited studies may bias the authentic estimates in the current meta-analysis. Accordingly, the results in our meta-analysis may be relatively conservative and should be interpreted in caution.

Take together, the current meta-analysis revealed that the pooled AKI in patients undergoing hip fracture surgery was approximately $17 \%$. Postoperative serum albumin was identified to be a potential significant risk factor for AKI. Further high-quality studies should be warranted to systematically clarify the prevalence and risk factors of AKI following hip fracture surgery.

\section{Abbreviations}

AKI: Acute kidney injury; Cl: Confidence interval; OR: odds ratio

\section{Declarations}

\section{Acknowledgements}

We thank the authors of the included studies for their help.

\section{Author contributions}

Yan-Li Zhang and Yan-Chuang Pu designed this meta-analysis. Yan-Li Zhang, Yan-Chuang, Pu, Jin Wang, and Zi-Cai Li extracted data. Jin Wang, Zi-Cai Li, and Hu-Lin Wang performed statistical analysis. Yan-Li Zhang and Yan-Chuang Pu wrote this manuscript.

\section{Funding}

No fund support

\section{Availability of data and materials}

All data are fully available without restriction. 


\section{Ethics approval and consent to participate}

This article does not contain any studies with human participants or animals performed by any of the authors

\section{Consent for publication}

Not applicable

\section{Competing interests}

The authors declare that they have no competing interests.

\section{Author details}

Department of Orthopaedics, Wuwei People's Hospital, Wuwei, Lanzhou 730030, China

\section{References}

1. Maxwell BG, Spitz W, and Porter J. Association of Increasing Use of Spinal Anesthesia in Hip Fracture Repair With Treating an Aging Patient Population. JAMA surgery. 2019; 155: 167-168.

2. Neuerburg C, Förch S, Gleich J, et al. Improved outcome in hip fracture patients in the aging population following co-managed care compared to conventional surgical treatment: a retrospective, dual-center cohort study. BMC geriatrics. 2019; 19: 330.

3. Marty P, Ferre F, Labaste F, et al. The Doppler renal resistive index for early detection of acute kidney injury after hip fracture. Anaesthesia, critical care \& pain medicine. 2016; 35: 377-382.

4. Lertjitbanjong P, Thongprayoon C, and Cheungpasitporn W. Acute Kidney Injury after Lung Transplantation: A Systematic Review and Meta-Analysis. 2019; 8

5. Thongprayoon C, and Kaewput W. Acute Kidney Injury in Patients Undergoing Total Hip Arthroplasty: A Systematic Review and Meta-Analysis. 2019; 8

6. Shin $\mathrm{KH}$, and Han SB. Early postoperative hypoalbuminemia is a risk factor for postoperative acute kidney injury following hip fracture surgery. Injury. 2018; 49: 1572-1576.

7. Partridge T, Jameson S, Baker P, et al. Ten-Year Trends in Medical Complications Following 540,623 Primary Total Hip Replacements from a National Database. The Journal of bone and joint surgery. American volume. 2018; 100: 360-367.

8. Thiele RH, Isbell JM, and Rosner MH. AKI associated with cardiac surgery. Clinical journal of the American Society of Nephrology : CJASN. 2015; 10: 500-514.

9. Meersch $\mathrm{M}$, and Zarbock A. Prevention of cardiac surgery-associated acute kidney injury. Current opinion in anaesthesiology. 2017; 30: 76-83

10. Moher D, Liberati A, Tetzlaff J, et al. Preferred reporting items for systematic reviews and meta-analyses: the PRISMA statement. PLoS medicine. 2009; 6: e1000097.

11. Stroup DF, Berlin JA, Morton SC, et al. Meta-analysis of observational studies in epidemiology: a proposal for reporting. Metaanalysis Of Observational Studies in Epidemiology (MOOSE) group. Jama. 2000; 283: 2008-2012.

12. Stang A. Critical evaluation of the Newcastle-Ottawa scale for the assessment of the quality of nonrandomized studies in metaanalyses. European journal of epidemiology. 2010; 25: 603-605.

13. Higgins JP, Thompson SG, Deeks JJ, et al. Measuring inconsistency in meta-analyses. BMJ (Clinical research ed.). 2003; 327: 557560.

14. Huedo-Medina TB, Sánchez-Meca J, Marín-Martínez F, et al. Assessing heterogeneity in meta-analysis: Q statistic or I2 index? Psychological methods. 2006; 11: 193-206.

15. Egger M, Davey Smith G, Schneider M, et al. Bias in meta-analysis detected by a simple, graphical test. BMJ (Clinical research ed.). 1997; 315: 629-634.

16. Begg CB, and Mazumdar M. Operating characteristics of a rank correlation test for publication bias. Biometrics. 1994; 50: 10881101. 
17. Craig P, Starks I, Bancroft G, et al. Is prophylactic Gentamicin associated with acute kidney injury in patients undergoing surgery for fractured neck of femur? Injury. 2012; 43: 2152-2155.

18. Ulucay C, Eren Z, Kaspar EC, et al. Risk factors for acute kidney injury after hip fracture surgery in the elderly individuals. Geriatric orthopaedic surgery \& rehabilitation. 2012; 3: 150-156.

19. Hong SE, Kim TY, Yoo JH, et al. Acute kidney injury can predict in-hospital and long-term mortality in elderly patients undergoing hip fracture surgery. PloS one. 2017; 12: e0176259.

20. Pedersen $A B$, Gammelager $\mathrm{H}$, Kahlert $\mathrm{J}$, et al. Impact of body mass index on risk of acute kidney injury and mortality in elderly patients undergoing hip fracture surgery. Osteoporosis international : a journal established as result of cooperation between the European Foundation for Osteoporosis and the National Osteoporosis Foundation of the USA. 2017; 28: 1087-1097.

21. Frenkel Rutenberg T, Bdeir A, Rozen-Zvi B, et al. Rate and Outcome of Acute Kidney Injury Following Hip Fracture Surgery in Diabetic Older Patients Treated with Renin-Angiotensin-Aldosterone Antagonists. Drugs \& aging. 2019; 36: 667-674.

22. Jang WY, Jung JK, Lee DK, et al. Intraoperative hypotension is a risk factor for postoperative acute kidney injury after femoral neck fracture surgery: a retrospective study. BMC musculoskeletal disorders. 2019; 20: 131.

23. Rantalaiho I, Gunn J, Kukkonen J, et al. Acute kidney injury following hip fracture. Injury. 2019; 50: 2268-2271.

24. Kang JS, Moon KH, Youn YH, et al. Factors associated with postoperative acute kidney injury after hip fractures in elderly patients. Journal of orthopaedic surgery (Hong Kong). 2020; 28: 2309499019896237.

25. Küpeli İ, and Ünver S. The Correlation between Preoperative and Postoperative Hypoalbuminaemia and the Development of Acute Kidney Injury with Respect to the KDIGO Criteria in the Hip Fracture Surgery in Elderly Patients. Turkish journal of anaesthesiology and reanimation. 2020; 48: 38-43.

26. Thongprayoon C, Kaewput W, Thamcharoen N, et al. Acute kidney injury in patients undergoing total hip arthroplasty: A systematic review and meta-analysis. Journal of clinical medicine. 2019; 8

27. Thongprayoon C, Cheungpasitporn W, Mao MA, et al. U-shape association of serum albumin level and acute kidney injury risk in hospitalized patients. PloS one. 2018; 13: e0199153.

28. Dos Santos RP, Carvalho A, and Peres LAB. Incidence and risk factors of acute kidney injury in critically ill patients from a single centre in Brazil: a retrospective cohort analysis. Scientific reports. 2019; 9: 18141.

29. Landgraf SS, Silva LS, Peruchetti DB, et al. 5-Lypoxygenase products are involved in renal tubulointerstitial injury induced by albumin overload in proximal tubules in mice. PloS one. 2014; 9: e107549.

30. Jain A, McDonald HI, Nitsch D, et al. Risk factors for developing acute kidney injury in older people with diabetes and communityacquired pneumonia: a population-based UK cohort study. BMC nephrology. 2017; 18: 142.

31. Wang C, Pei YY, Ma YH, et al. Risk factors for acute kidney injury in patients with acute myocardial infarction. Chinese medical journal. 2019; 132: 1660-1665.

32. Hinson JS, Ehmann MR, Al Jalbout N, et al. Risk of Acute Kidney Injury Associated With Medication Administration in the Emergency Department. The Journal of emergency medicine. 2020; 58: 487-496.

\section{Figures}




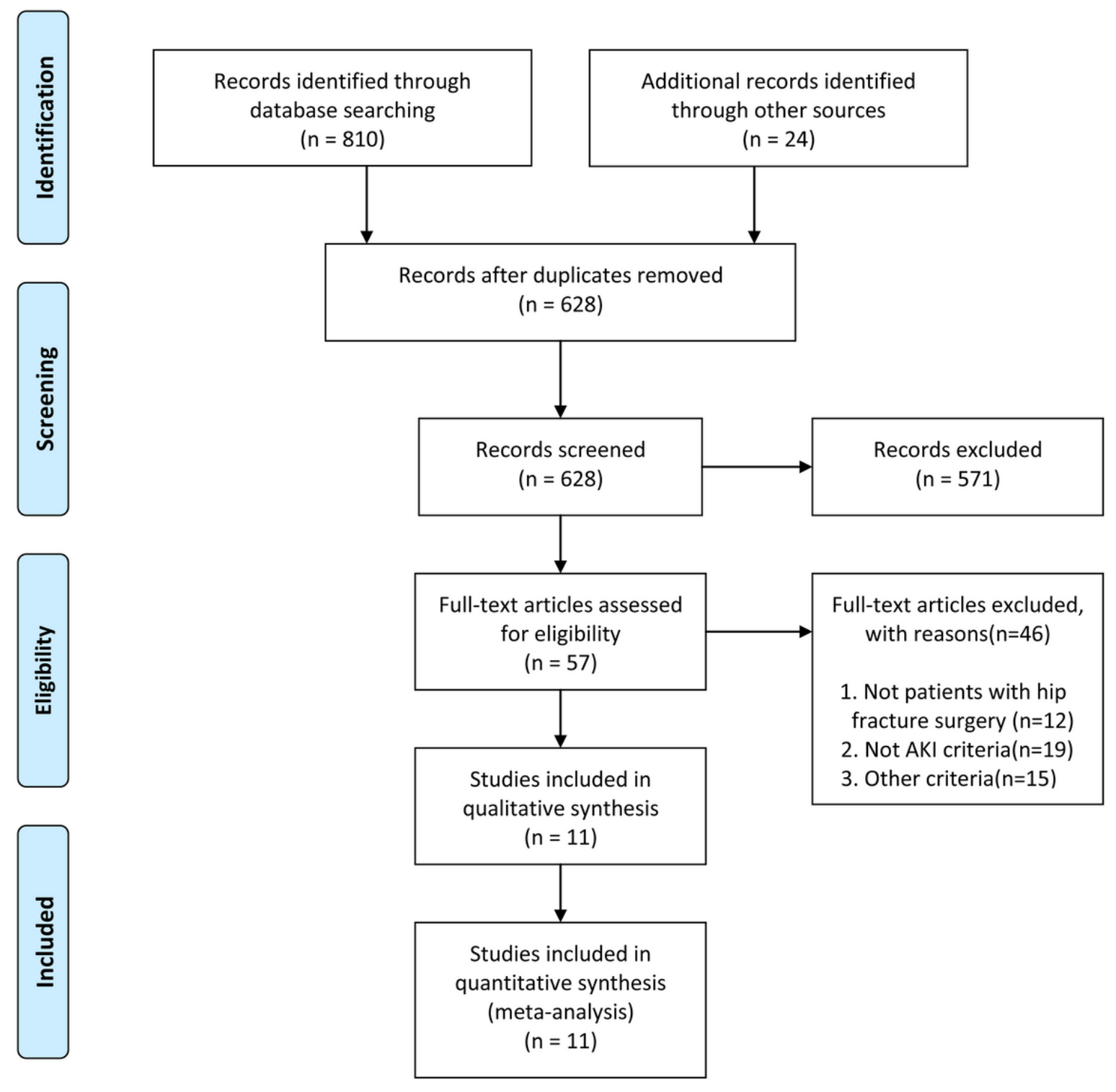

\section{Figure 1}

Flow diagram of the selection of studies for this meta-analysis 


\begin{tabular}{|c|c|c|c|}
\hline Craig 2012 & $\rightarrow$ & $0.12(0.06,0.18)$ & 8.41 \\
\hline Ulucay 2012 & $\rightarrow$ & $0.18(0.12,0.25)$ & 8.38 \\
\hline Pedersen 2016 & - 1 & $0.13(0.12,0.13)$ & 10.97 \\
\hline Hong 2017 & $1+$ & $0.21(0.17,0.25)$ & 9.93 \\
\hline Shin 2018 & $\leftarrow 1$ & $0.12(0.09,0.15)$ & 10.34 \\
\hline Frenkelrutenberg 2019 & $1 \rightarrow$ & $0.25(0.20,0.31)$ & 8.77 \\
\hline Jang 2019 & $\rightarrow$ & $0.18(0.13,0.22)$ & 9.39 \\
\hline Rantalaiho 2019 & $\rightarrow \quad 1$ & $0.08(0.06,0.11)$ & 10.50 \\
\hline Kang 2020 & $\star$ & $0.05(0.03,0.06)$ & 10.75 \\
\hline Marty 2016 & 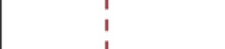 & $0.60(0.47,0.74)$ & 4.49 \\
\hline K"1peli 2020 & $\longrightarrow$ & $0.28(0.21,0.34)$ & 8.07 \\
\hline Overall $(I-$ squared $=95.0 \%, p=0.000$ ) & & $0.17(0.14,0.21)$ & 100.00 \\
\hline NOTE: Weights are from random effects analysis & i & & \\
\hline $\begin{array}{c}1 \\
-.743\end{array}$ & & +3 & \\
\hline
\end{tabular}

\section{Figure 2}

Forest plot for prevalence of AKI in patients undergoing hip fracture surgery using random-effects mode. 
Meta-analysis random-effects estimates (linear form)

Study ommited

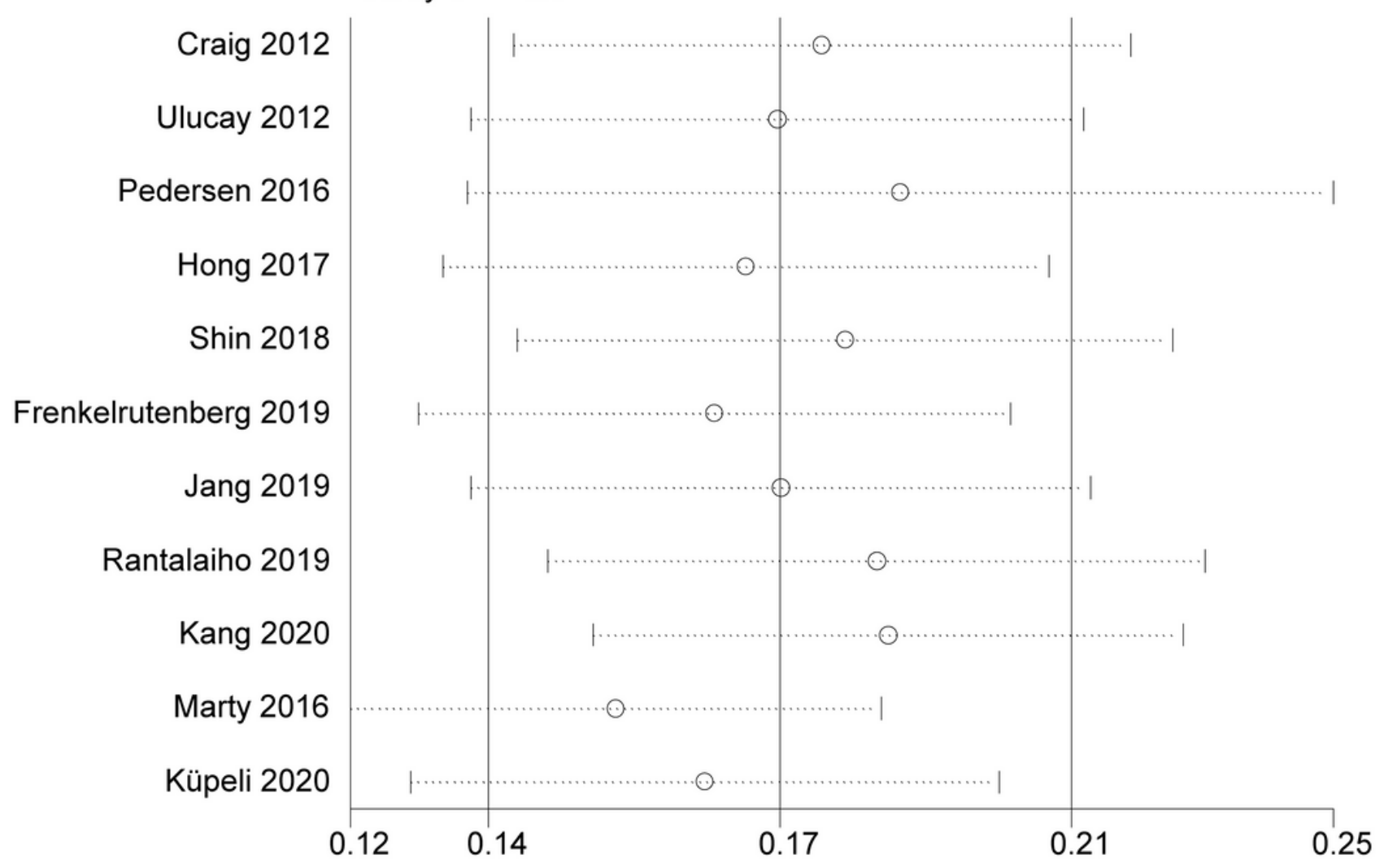

Figure 3

Sensitivity analysis for prevalence of AKI in patients undergoing hip fracture surgery in the meta-analysis. 
Begg's funnel plot with pseudo $95 \%$ confidence limits

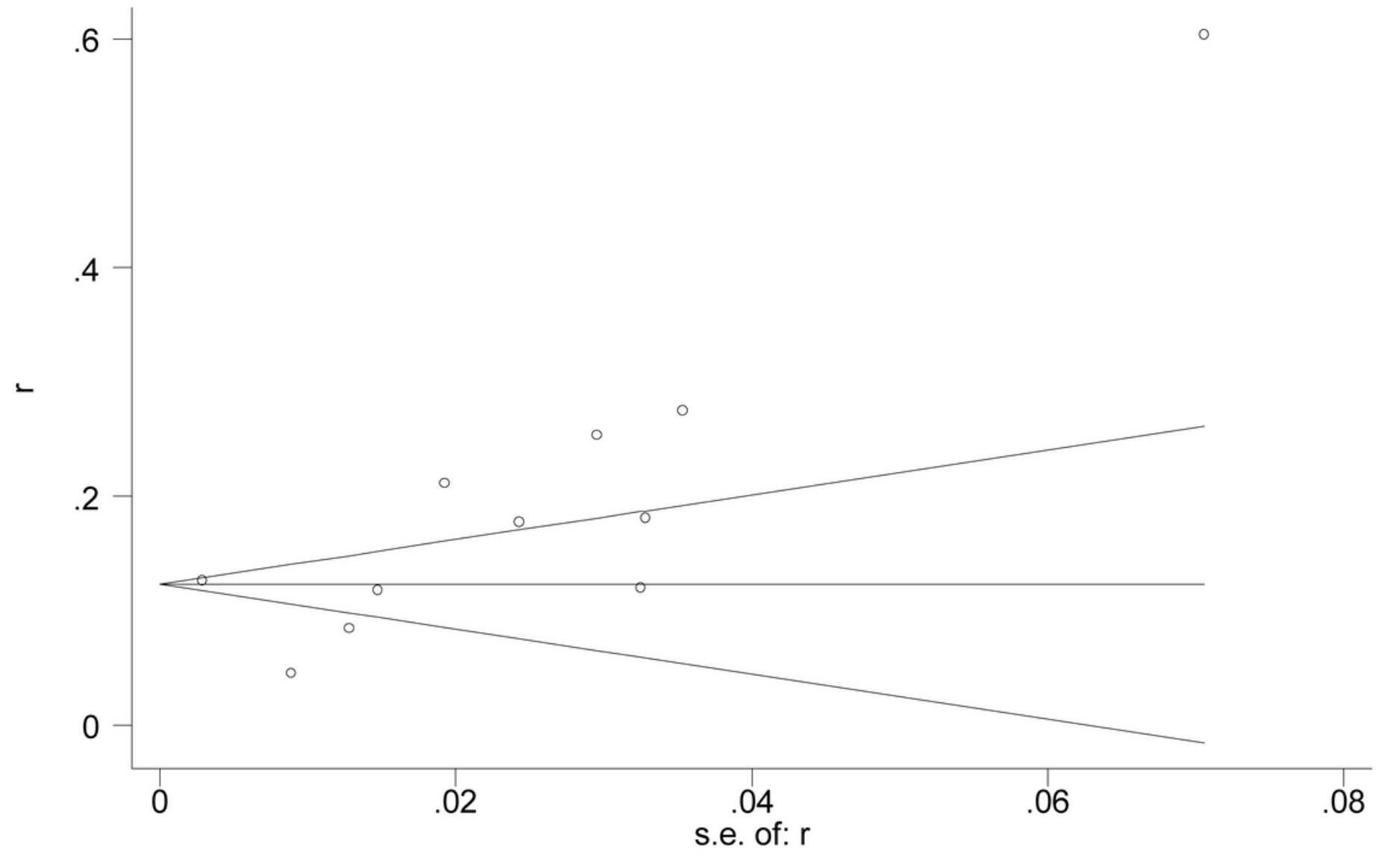

Figure 4

Funnel plot for prevalence of AKI in patients undergoing hip fracture surgery. (Egger's test, $p=0.258$ and Begg's test, $p=0.087$ ). 